\title{
Land subsidence evolution and controlling mechanisms near Mexico City: environmental planning and management
}

\author{
M. A. Ortega-Guerrero \\ Centro de Geociencias, \\ Universidad Nacional Autónoma de México, México
}

\begin{abstract}
Mexico City is situated in the Basin of Mexico on a highly compressible lacustrine aquitard that overly highly productive aquifers of both volcanic and sedimentary origin. This aquitard contributes with regional recharge through leakage to the underlying alluvial-pyroclastic regional aquifer, from which about $50 \mathrm{~m}^{3} / \mathrm{sec}$ are pumped to supply water for the Metropolitan Area of Mexico City, to nearly 25 million inhabitants. The extensive lacustrine Chalco Plain in the southeastern part of Mexico City is underlined by an aquitard up to $300 \mathrm{~m}$ thick. This area was a shallow lake until the 1940s when it was drained for agricultural use and human habitation. In the middle 1980s, when major groundwater extraction began with the onset of the Santa Catarina Well Field in the middle of the Chalco Plain, subsidence of 2 m occurred between 1984 and 1989, causing a shallow lake to form and gradually expand. Land subsidence in the central part of the Chalco Basin has increased to $0.4 \mathrm{~m} / \mathrm{yr}$ since 1984 and by 1991 total subsidence had reached more than $10 \mathrm{~m}$ at present. The rapid land subsidence in this area is causing the accumulation of meteoric waters during the rainy season resulting in extensive flooding of farmland and potentially urban areas. Three different stages of lake growth were identified: (i) ponding (1984-1989), (ii) lake formation (1990-1993), and (iii) bifurcation (1994-present). In this last stage, the local presence of a basalt layer in the middle of the Santa Catarina Well Field is causing differential consolidation and forming a local topographic elevation that permits the development of two separated lakes. Since the middle of the 1990s, the new lake conditions are permitting the growth of few aquatic native plants and arrival of different species of migratory birds: therefore, environmental planning and management for the southernmost end of the Basin of Mexico is proposed through the development of a series of connected artificial lakes to control urban growth, to improve environmental conditions of the MAMC, to develop ancient agricultural production systems such as the floating gardens or "Chinampas" and recreational facilities with proportional benefits to the social and economical sectors.
\end{abstract}

Keywords: land subsidence, consolidation, artifitial lake development, environmental planning. 


\section{Introduction}

Most of Mexico City is constructed over this highly compressible aquitard within the Basin of Mexico and is surrounded by volcanic mountains (Figure 1). The Basin is hydrologically closed and as such, a quiescent series of interconnected lakes occupied the basin floor prior to the construction of an artificial drainage system in 1789 (Bribiesca [1]). Groundwater is extracted from a regional alluvial-pyroclastic aquifer and from a fractured volcanic aquifer for supplying almost 25 million inhabitants and some $30 \%$ of the nation's industry in the Metropolitan Area of Mexico City (MAMC) INEGI and INE [1]. Both aquifers underlie a thick sequence (between 50-300 m) of clayey lacustrine sediments, considered in hydrogeological terms as a regional aquitard Ortega and Farvolden [2]. Approximately $52 \mathrm{~m}^{3} / \mathrm{s}$ of groundwater has been extracted from these aquifers, out of a total of $65 \mathrm{~m}^{3} / \mathrm{s}$ consumed in the MAMC [1] and NRC-AICANI [3].

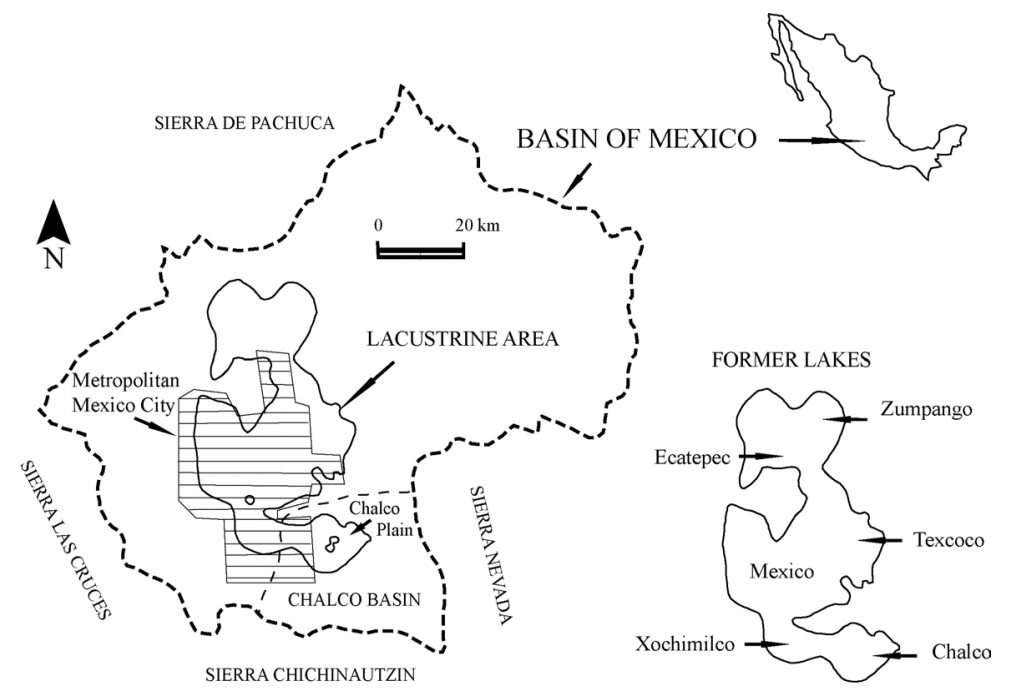

Figure 1: Location of the Chalco Basin within the Basin of Mexico and former lakes.

Groundwater extraction from the regional alluvial-pyroclastic aquifer underneath the lacustrine aquitard started in the XIX century and became extensive during the 1930s Hiriart and Marsal [4]. Extensive land subsidence was documented since the early 1940s in downtown Mexico City over several decades due to depressurization and consolidation of the aquitard caused by heavy pumping, particularly in the middle of the city Carrillo [5]. Indeed, the magnitude of the subsidence became so extreme in some locations that severe problems arose related to building foundations, sewer drainage, and subway transportation system. 
To minimize further damage from additional subsidence within the MAMC many of the downtown wells were taken out of production and new well fields were constructed on the outskirts of the city and groundwater from the basin was also imported to satisfy water demands. In the southern part of the Basin of Mexico, the most recent well field to be added to the urban supply system is located within the Chalco Basin (Figure 3), where one of the ancient lakes once existed (Figure 1). This new well development has resulted in the partial transfer of the land subsidence problem from within the MAMC to the nearly agricultural and urban areas of the Chalco Plain.

The main goal of this work is to update the land elevation survey up to 2005 and to present hydrological evolution of the development of the New Chalco Lake and environmental conditions recorded since 1988 to 2005. A plan for environmental improvement is suggested throughout the development of a series of artificial lakes, in the southern end of the Basin, by controlled groundwater extraction from the regional aquifer, with different environmental, social and economic impacts.

\section{Hydrogeology of the Chalco Basin}

The Chalco Plain was a shallow lake until the 1940s when it was drained for agricultural use and human habitation. Historic information indicates that the Chalco Plain was an area of fresh ground-water discharge prior to the onset of heavy groundwater extraction from the semiconfined aquifer, in contrast with the former Texcoco Lake that was recognized since the Aztecs by its high salinity content.

The thickness of the lacustrine aquitard increases from the edges of the former lake to a maximum thickness of about $300 \mathrm{~m}$ in the centre of the plain (Figures 2 and 3) Ortega-Guerrero et al. [6]. The lacustrine sediments are interbedded with Quaternary basalts and pyroclastic deposits near Sierra Chichinautzin and in the vicinity of the Santa Catarina Well Field (SCWF). Of particular importance, for this work, is the basalt interbedded with the lacustrine sequence in the middle of the SCWF, which has influenced differential land subsidence and that will be discussed below. A regional granular aquifer underlies the lacustrine aquitard; consisting primarily of alluvial and pyroclastic material and ranging in thickness between 200 and $400 \mathrm{~m}$. Tertiary volcanic bedrock is below the granular aquifer (Figures 2 and 3).

Detailed investigations of transient groundwater flow and land subsidence in the Chalco Basin reveal sever exploitation of the regional aquifer system, resulting in progressive lowering of piezometric levels in the aquifer and a fast decline in land surface. Aquifer depressurization and land subsidence began throughout the Chalco Basin prior to the construction of the SCWF in the middle of the plain in 1984. Since pumping started from the SCWF the regional piezometric surface in the aquifer has been drooping at a rate of about 1.5 $\mathrm{m} / \mathrm{year}$. The present rate of land subsidence in the middle of the clay plain is near $0.40 \mathrm{~m} / \mathrm{year}$, the highest within the Basin of Mexico. Consequently, 
accumulation of rain and surface water is occurring in this topographic depression Ortega-Guerro et al. [7].

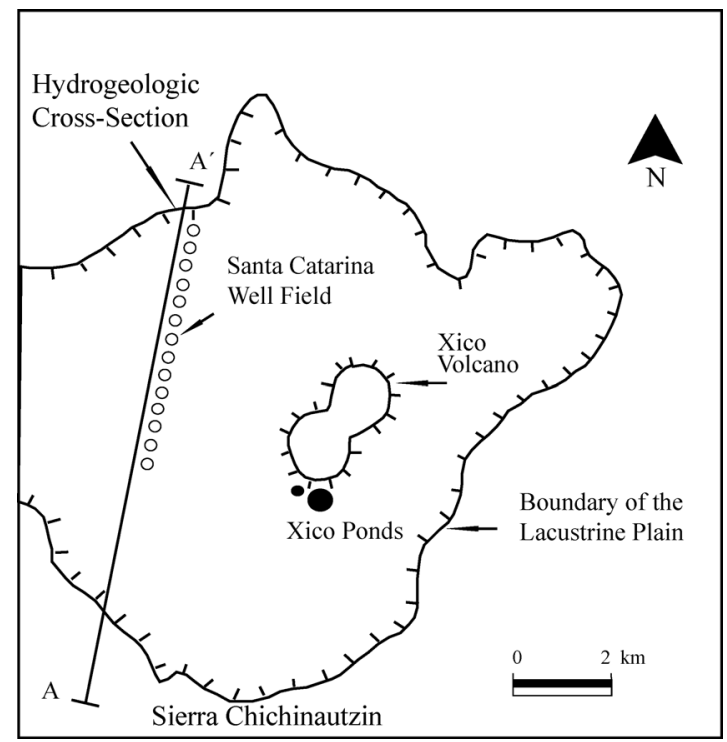

Figure 2: Location of the Santa Catarina Well Field and hydrogeologic crosssection (Modified from Ortega-Guerrero et al. [6]).

A

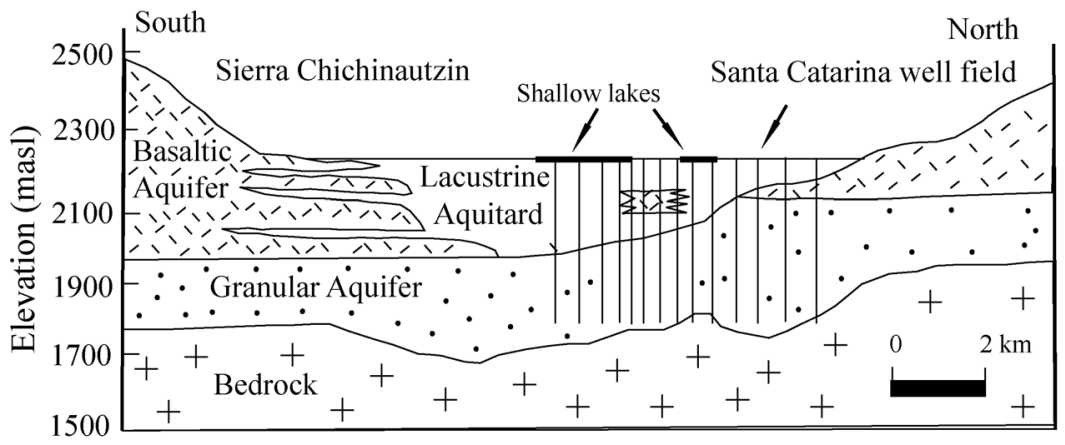

Figure 3: Hydrogeologic cross-section showing the distribution of the lacustrine clayey aquitard and the interbedded basalts (Modified from Ortega-Guerrero et al. [6]).

Land subsidence has caused elevation gradients to change, such a degree, that part of the surface water drainage network is not longer functional and a series of 
pumps are used to drain surface water to the nearby Texcoco area (Figure 1). Consequently, more of the land surface is progressively inundated, particularly during the rainy season and flooding has not only taken agricultural land out of production but has also begun to threatened urban areas that are expanding from the mountain slopes and edges of the former lakes onto the plain. In 2000, extraordinary rain events caused the northeastern urban area of Valle de Chalco, to become flooded with a mixture of rainwater and industrial-urban wastewater, affecting the health of people and their property.

Numerical simulations of land subsidence based on numerous observation piezometer sites carried out by Ortega-Guerrero et al. [6], suggest that under current pumping rates, total land subsidence in the area of thickest lacustrine sediment will reach $15 \mathrm{~m}$ by the year 2010 (Figure 4). If pumping were reduced to the extent that further decline in the potentiometric surface is prevented, total maximum subsidence would be significantly less, about $10 \mathrm{~m}$, and the rate would nearly cease by 2010 (Figure 4). This analysis demonstrates that the new shallow lake conditions will prevail for several decades with enormous environmental effects. How can this hydrologic, landscape, ecologic and environmental situation can be controlled for environmental benefits is the topic of this work.

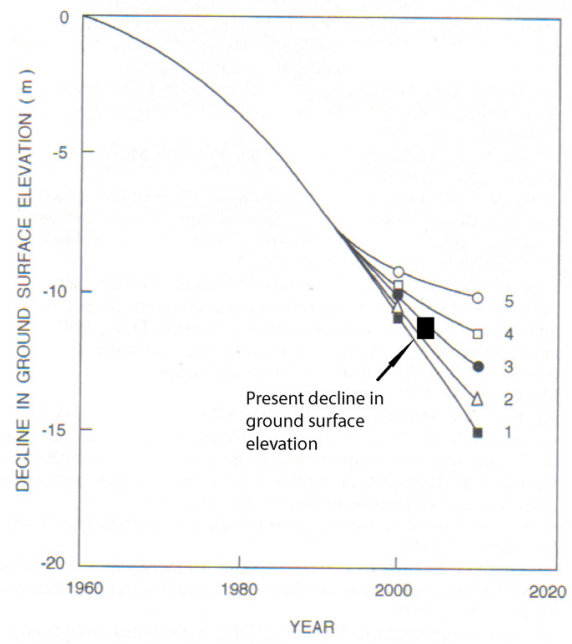

Figure 4: Predicted transient evolution of the total subsidence in the middle of the Chalco Plain if the rate of drawdown is reduced by, $0 \%$ (case 1), $25 \%$ (case 2), 50\% (case 3), 75\% (case 4) and 100\% (case 5). (Modified from Ortega-Guerrero et al. [6]).

Of concern of this region therefore is the total magnitude of the land subsidence and the future subsidence rate that is likely to result from the current groundwater extraction system. There are also multiple geo-environment concerns at the Chalco Basin particularly on: the new hydrological and landscape 
ecology, environmental planning and management based on sustainable groundwater resources exploitation, flooding hazards, between others.

The information published in Ortega-Guerro et al. [7] and Ortega-Guerrero et al. [6] was augmented with new data such as land elevation surveys, evolution of hydraulic response of the aquitard and evolution of lake growing, identification of environmental modifications derived from the process of pumping-land subsidence, to provide elements for environmental planning and management.

\section{Results and discussion}

\subsection{Evolution of land subsidence and lake growth}

Based on physical observations of the extension of the new Chalco Lake with time, three different periods of lake evolution are identified: (1) Ponding stage, (2) New lake stage, and (3) Bifurcation of the lake.

(1) Ponding stage. In 1987 a series of nests of drive point piezometers where installed in the southern edge of the Chalco Plain to measure hydraulic heads in the upper 20 meters of the lacustrine sequence. In 1988 this site and other isolated sites became flooded as shown in Figure 5. Those sites were located at particular area that had a total drop in land surface elevation of $2 \mathrm{~m}$ in the period 1984 to 1989 . The network of surface water canals to drain surface water became no functional, and in order to avoid flooding to the nearby urban areas on the Chalco Plain, a system of electric pumps were installed. The Xico ponds are due to the load of the Xico Volcano and existed before operation of the SCWF.

(2) New Lake stage. Progressive consolidation of the aquitard due to aquifer pumping in the SCWF caused a total land subsidence of about $7 \mathrm{~m}$ in the central part of the plain. In August 1991 the lake extended to an area of about 4 $\mathrm{km}^{2}$ (400 ha) as shown in Figure 5. The roads parallel to the SCWF were progressively elevated to provide access to the wells.

(3) Bifurcation of the lake. In 1994 a second lake began to form in the northern part of the Chalco Plain. The bifurcation is associated with the presence of a basalt unit interbedded with the lacustrine sequence in that part of the plain (Figure 3). This figure also shows the position of the basalt unit and the present position of the two lakes. This basaltic layer is causing differential consolidation of the aquitard and potentially will maintain the lakes separated for some period of time until a lateral connection may be reached. The extension of the lakes in 2005 is also shown in Figure 5, where development of two individual lakes is observed, covering a total area of about $6 \mathrm{~km}^{2}$ (600 ha). 


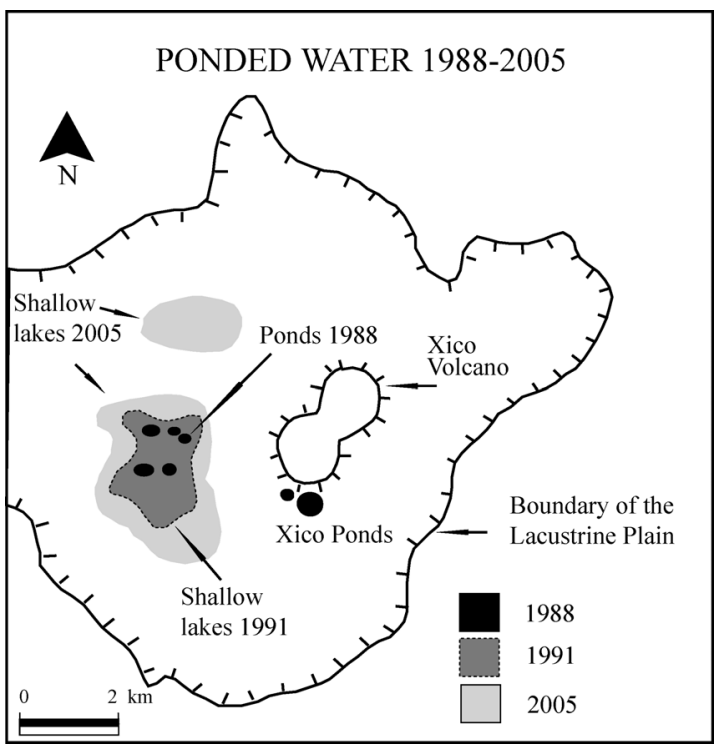

Figure 5: Evolution of the shallow lakes. The bifurcation of the lake in 2005 is controlled by a basalt unit interbedded with the lacustrine sequence in the middle of the Santa Catarina Well Field Modified from OrtegaGuerrero et al. [7].

\subsection{Environmental situation}

In the first stage of the New Chalco Lake formation, land subsidence in the middle of the Chalco Plain caused elevation gradients to change and part of the surface water drainage network was not longer functional and the wastewater from urban areas and industry, without previous treatment, accumulated towards this shallow lake, causing sever problems in water quality with total absence of wild life. However, as land subsidence increased and extraordinary rainwater events flooded the topographic depression, in the 1990s, more favorable water quality conditions developed, permitting the growth of few aquatic native plants and arrival of different species of migratory birds. This unexpected situation may open new possibilities for environmental planning and management in the Basin of Mexico.

Water balance at the New Chalco Lake is not well understood, it captures between $7 \mathrm{E}+06$ to $10 \mathrm{E}+06 \mathrm{~m} 3 / \mathrm{yr}$ of rainwater; real evaporation and contributions from sewage are not well known. Groundwater-surface water interaction and the new climatological conditions in addtion to chemical and isotopic characterization of the new lake are the focus of present research. 


\subsection{Developing a series of connected lakes in the southern end of the Basin of Mexico}

There are different well fields in the southern lacustrine area of Mexico City. A well-planned and controlled extraction of groundwater from the underlying alluvial-pyroclastic and basaltic aquifers can, progressively, generate adequate amounts of consolidation of the overlying compressible aquitard, to develop a series of topographic depressions (Figure 6) that can be filled with rainwater, runoff and perhaps some treated water. The wells would continue to provide drinking water to the City while causing progressive consolidation.

Groundwater extraction must be designed to progressively reduce hydraulic conductivity at the bottom of the aquitard as demonstrated by Rudolph and Frind [8] and avoid an excess of stress that may cause fracturing of the aquitard as demonstrated by Aguilar-Perez et al. [9]. Fracturing of the aquitard may cause important leaks.

The area proposed for lake development is shown in Figure 6. The basic idea is to connect the Xico ponds, with the New Chalco Lake, Mixquic, Tlahuac and Xochimilco. The Mixquic and the Tlahuac areas require further consolidation development to connect them with the other lakes.

In the Texcoco former lake, the Nabor Carrillo Lake was developed, in the 1960 s, by pumping a 2-3 m thick sandy layer located about $20 \mathrm{~m}$ below a clayey aquitard to form a topographic depression, which was filled with water. This method required a large number of shallow wells that produced high salinity content in the water, which localy was used to produce caustic soda Marsal [10]. However cost benefit analysis may be needed to choose the method for consolidating the aquitard.

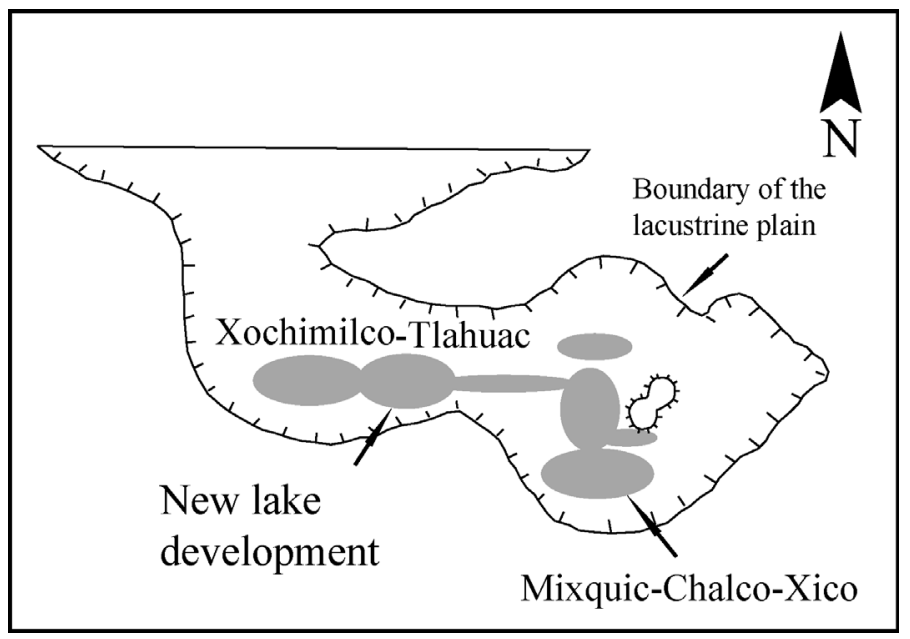

Figure 6: Proposed development of a series of connected lakes towards the southern end of the Basin of Mexico to improve environmental conditions. 
This development of a series of connected lakes by controlled consolidation would progressively improve environmental conditions and ultimately improve social and economic situation of the inhabitants of this region of the Basin through payment of environmental services and ecotourism. Food production using the system of Floating Gardens or "Chinampas" from the Aztec tradition and still use in Xochimilco and Mixquic may represent an additional attraction of this project.

\section{Conclusions}

The extensive lacustrine Chalco Plain in the southeastern part of Mexico City is underlined by an aquitard up to $300 \mathrm{~m}$ thick. Land subsidence in the central part of the Chalco Basin has increased to $0.4 \mathrm{~m} / \mathrm{yr}$ since 1984 and by 1991 total subsidence had reached $8 \mathrm{~m}$ and more than $10 \mathrm{~m}$ at present. The rapid land subsidence in this area is causing the accumulation of meteoric waters during the rainy season resulting in extensive flooding of farmland and potentially urban areas. Three different stages of lake growth were identified: (i) ponding (19841989), (ii) lake formation (1990-1993), and (iii) bifurcation (1994-present). In this last stage, the local presence of a basalt layer in the middle of the Santa Catarina Well Field is causing differential consolidation and forming a local topographic elevation that permits the development of two separated lakes. This area is still susceptible to the highest potential land subsidence effects as a result of groundwater extraction of anywhere in the basin. Environmental planning and management for the southernmost end of the Basin of Mexico is proposed through the development of a series of connected artificial lakes to control urban growth, to improve environmental conditions of the MAMC, to develop ancient agricultural production systems such as the floating gardens or "Chinampas" and recreational facilities with benefits to social and economical sectors.

\section{References}

[1] Bribiesca, C.J.L. Hidrología Histórica del Valle de México [Historic hydrology of the Valley of Mexico]. Ingeniería Hidráulica, Vol. XIV, No 1, México . pp. 107-125, 1960.

[2] Ortega, G.M.A. and Farvolden, R.N. Computer analysis of regional groundwater flow and boundary conditions in the Basin of Mexico. Journal of Hydrology 110, pp. 271-294, 1987

[3] NRC-AIC-ANI. National Research Council, Academia de la Investigación Científica and Academia Nacional de Ingeniería. México City's water supply. National Academic Press, Washington DC, 1995.

[4] Hiriart, F. and Marsal, R.J. The subsidence of México City. In volumen Nabor Carrillo, Secretaría de Hacienda y Crédito Público. México, Vol II, pp. 109-147, 1969.

[5] Carrillo, N. Influence of Artesian Wells in the Sinking of Mexico City. Comisión Impulsora y Coordinadora de la Investigación Científica, 
Anuario 47. In: Volumen Nabor Carrillo, pp. 7-14, Secretaría de Hacienda y Crédito Público, México, 1969.

[6] Ortega-Guerrero, M.A., Rudolph, D.L. and Cherry, J.A. Análisis of longterm land subsidence near México City: Field investigations and predictive modeling. Water Resources Research, 25(11), pp. 3327-3341, 1999.

[7] Ortega-Guerrero, M.A., Cherry, J.A. and Rudolph, D.L. Large-scale aquitard consolidation near Mexico City. Ground Water, 31(5), pp. 707$718,1993$.

[8] Rudolph, D.L. and Frind, E.O. Hydraulic response of hyghly compressible aquitards during consolidation. Water Resources Research, 27(1), pp. 1730, 1991.

[9] Aguilar-Perez, L.A., Ortega-Guerrero, M.A., Hubp, J.L. and Ortiz, D.C. Análisis nemérico acoplado de los desplazamientos verticales $y$ generación de fracturas por extracción de agua subterránea en las proximidades de la Ciudad de México. Revista Mexicana de Ciencias Geológicas. In Press, 2006.

[10] Marsal, R.J. Development of a lake by pumping-induced consolidation of soft clays. In volumen Nabor Carrillo, Secretaría de Hacienda y Crédito Público. México, Vol II, pp. 229-266, 1969. 